\title{
Innovation and Social Impact in Higher Education: Some Lessons from Tohoku University and the Open University of Hong Kong
}

\author{
Carol Poon Man Wai \\ The Open University of Hong Kong, Hong Kong, China \\ Email:cpoon@ouhk.edu.hk
}

How to cite this paper: Wai, C.P.M. (2017) Innovation and Social Impact in Higher Education: Some Lessons from Tohoku University and the Open University of Hong Kong. Open Journal of Social Sciences, 5, 139-153.

https://doi.org/10.4236/jss.2017.59011

Received: August 21, 2017

Accepted: September 11, 2017

Published: September 14, 2017

Copyright $\odot 2017$ by author and Scientific Research Publishing Inc. This work is licensed under the Creative Commons Attribution International License (CC BY 4.0).

http://creativecommons.org/licenses/by/4.0/

(c) (i) Open Access

\begin{abstract}
In recent years, Hong Kong Education Authority has been zealously encouraging schools to reform the current teaching profession, so as to raise students' critical thinking and creativity, as well as to enhance their innovation and motivation of learning. Along with this, American scholars (Clements 2013 [1]; Levi 2013 [2]; McCarthy 2009 [3]; McWilliam 2009 [4]) have encouraged the educational circles vigorously that they should apply innovation teaching in the teaching profession. Actually this strategy has been widely examined in United State and Japan for a period of time and the outcome is quite fruitful. Based on the lessons from Massachusetts Institute of Technology, this paper aims to shed light on a heavily under-researched multidisciplinary area: innovation and education. With a focus in the Tohoku University in Japan and The Open University of Hong Kong, this paper will examine the issue via cultural history, education policy and related social systems together with "the traditional custom". Furthermore, this paper aims to redefine the concept of innovation in nowadays higher education teaching, to serve as a reference for potential change agents as they consider ways and means to created improved learning environments at universities and institutions, to enhance the educational circles' interest and understanding in utilizing such new medium as well as the social power. And finally it examines and compares the social impact on the introduction of innovation teaching in higher education profession. Apart from literature studies, this paper will carry out a field study and interview in both Hong Kong and Japan, and also field observation in Tohoku University.
\end{abstract}

\section{Keywords}

Innovation, Social Impact, Higher Education Policy, Traditional Customs, 
Curriculum Development

\section{Introduction}

Academic research is often theory-based, thus impractical and fails to generate immediate results. It takes time to cause significant influence on our society. As Gene Block, Chancellor of UCLA, rightly commented in his speech "Globalization and Innovation: The Transformation of Higher Education in the 21st Century" at the International Presidential Forum on Global Research Universities (2012) [5]: "education and scientific inquiry generally are inherently long-term propositions-requiring patient, painstaking, long-term investments to produce meaningful results. There is no such thing as instant education, even with the fastest Internet speeds and massive bandwidth."

In the age of globalization while everything is closely and instantly connected, however, it is important that the knowledge nurtured at the university is able to transfer to the social world more noticeably and directly. In his infamous work The Postmodern Condition: A Report on Knowledge, Jean-François Lyotard argues that modern science legitimates itself with reference to a metadiscource appealing to some grand narrative, while postmodern is the incredulity towards metanarratives. The report is based on Lyotard's observation in various fields of sciences and universities, or in his own words, in the field of "knowledge in computerized societies." The problem of computerization in highly developed regions can be summarized as follows: science seems to be subordinated to the prevailing powers than ever before, and the question of knowledge is more than ever a question of government. According to Lyotard, "The old principle that the acquisition of knowledge is indissociable from the training (Bildung) of minds, or even of individuals, is becoming obsolete and will become ever more so... Knowledge is and will be produced in order to be sold, it is and will be consumed in order to be valorised in a new production: in both cases, the goal is exchange. Knowledge ceases to be an end in itself, it loses its 'use-value'." (Lyotard 1984: pp. 4-5) [6], In other words, knowledge (or information) is worthless if it is not transferable to business sector.

In recent years, University Grant Committee (UGC) is increasingly promoting knowledge transfer in higher education. UGC defines knowledge transfer as follows: "The systems and processes by which knowledge, including technology, know-how, expertise and skills are transferred between higher education institutions and society, leading to innovative, profitable or economic or social improvements." The emphasis on innovation and social impact can be found in University Grant Committee (UGC)'s various documents. For examples, the UGC will "support the continuous development of the higher education sector 
to achieve greater impact and recognition, and as a source of innovation and ideas for the community." "Academic departments were encouraged to develop effective and innovative teaching and learning skills and pedagogies with more usage of web-based/e-learning and online multimedia materials."3

Higher education in Hong Kong is undergoing a series of reforms to raise students' critical thinking and creativity, as well as to enhance their innovation and motivation of learning. Concerning the problem of innovation and social impact, scholars (Clements, 2013; Levi, 2013; McCarthy, 2009; McWilliam, 2009) have encouraged the educational circles vigorously that they should apply innovation teaching in the teaching profession. This strategy has been widely examined in United State and Japan for a period of time and the outcome is fruitful. However, innovation and social impact are relatively under-estimated in Hong Kong. Generally speaking, conventional research (even without any aspect of innovation and social impact) is still regarded as the most important role of universities. As a result, innovation and social impact are not primary concern for most institutions. Teaching in Hong Kong is rather lacking innovation. Knowledge transfer is still technological oriented.

This paper, based on the lessons from the Massachusetts Institute of Technology (MIT) will report the application of innovation at the Tohoku University (TU) and The Open University of Hong Kong (OUHK). It will examine the concept of innovation in higher education teaching nowadays, serve as a reference for potential change agents as they consider ways and means to created improved learning environments at universities and institutions, and enhance the educational circles' interest and understanding in utilizing such new medium as well as the social power. The reason for choosing MIT and TU is that the former is a representative institute for innovation research with social impacts, while the latter is a research university in Japan suffered from the Great East Japan Earthquake in 2011 but showed a promising approach to implement innovative curriculum. And in addition, both of the universities are actively demonstrated in innovative teaching in different disciplines and this paper is going to discuss their social impacts in details and their contribution to the society. Last but not least, the case study of the Japanese Studies programme at OUHK will serve as a reference, if not model, for teaching professionals in shaping innovated learning environments at universities and institutions in Hong Kong and neighbor regions.

\section{Defining "Innovation"}

In the midst of 21st century, innovation has become an essential ingredient in creating and sustaining a culture of performance in higher education. Innovation keeps transforming higher education and creatives' attractive alternatives to existing systems of education. To most people, the term innovation will immediately

${ }^{2}$ UGC report 2012-13, p. 11.

${ }^{3}$ Ibid., p. 47. 
and inevitably bring into mind technology. In a teaching environment, it is often understood as the application of technology in enhancing teaching effectiveness and streamlining back office functions through the usage of presentation software, tablets, and course management tools, online collaboration tools, MOOC and so forth. In an age of digital technology, the majority of people tend to believe that technology integration in the classroom helps students better engage and take more proactive control over their learning. It is undeniable that technology, while reimagining time and space, offers some exciting alternatives that help enrich the traditional education system with more interactive opportunities. However, does a technological tool alone imply creativity and innovation? Is there another form of innovation?

Indubitably, the definition of innovation does not end there. According to White \& Glickman (2007: p. 97) [7], the term innovation refers to the introduction of a new idea, method or device. Peter Drucker suggested that innovation is "a change that creates a new dimension of performance" and U.K. Department of Trade and Industry stated that innovation is the successful exploitation of new ideas (Goldsmith, Hessellbein and Somerville, 2010: xi) [8]. These all suggested that the definition of innovation is not only limited to sciences and technology. Based on the above inspiration, this paper goes for the idea of White \& Glickman (2007), that innovation can applied to higher education where innovation can refer simply to some new way of doing things. Moreover, this paper is not only concerned with innovation in education merely for the sake of uniqueness, but the innovation as an essential ingredient in creating and sustaining a culture of performance in higher education. Those performances are the "social impact" to the society. Simply speaking, social impact is the effect of an activity on the social structure of the community toward individuals and groups (Gidden, 2001: p. 213) [9]. Thus, this paper considers "innovation" to be "a new approach that brings and improved result."

According to Clayton Christensen (2012) [10], a professor in Harvard Business School, innovation can be grouped into two categories: disruptive and sustaining. Disruptive innovations are those that break with current practices to serve a new group of people (or serve and existing population in radically different ways), and in so doing, create entirely new architecture and ecosystems-such as the shift from horses to automobiles. Meanwhile, sustaining innovations are generally improvements within the existing architecture of current system-such as moving from gas-powered to eco cars. In the case of innovation in research and teaching, it must better embrace not only the steady sustaining innovations, but also the truly disruptive innovations. For instance, innovations could come from people and organization outside of the traditional system. It will lead to a fundamental change in the way the system looks and works, and ultimately to a dramatic improvement in outcomes (social impact) for the students in order to meet their need. In order to find out how "innovation" can be practiced in higher education, an examination of how "to innovate" is a must. 
Hereafter, we will introduce two important concepts in innovation: platform and process.

Although we have defined "innovation" as a "new approach that brings and improved result," most people will still have a picture of a new "product" in their mind when they discuss about innovation. Even if much innovation is in fact at the "product" level, some of the most important innovation is at the "platform" level. "Platform" is hardware in technology. It can also be any kind of architecture, software framework or infrastructure that allows different specialists to group together and contribute. Steven (2009) [11], had demonstrated a very interesting illustration to explain "platform" in innovation. The internet, are examples of different kinds of technology platforms that each enable entirely new markets of independent innovators to emerge. The innovation enabled by the internet was not limited on a specific product, but it connects people from all around the world and share with each other. This infrastructure is a combination of computer language and technology that enable independent computer users to communicate across the world. The other example that Kim had pointed out is iPhone. It is another "platform" enabled new innovators to emerge. It provides a channel for different people to do new and innovative things like creating "apps (applications)."

From the examples above, we should notice the importance of a "platform" for innovation development, and the crucial idea lies in the point that "platform" is not only limited to whether it is small or big, or whether it is a software or product. The key elements here is that "platform" is a place/channel for people to group together to share or work together in order to create and develop new idea/things. And in this paper, we will demonstrate two important "platform" for innovation development in higher education, one is the Media Lab in Massachusetts Institute of Technology (MIT) and the other is Sciences Café in Tohoku University (TU). Both serve as excellent models for universities and institutions in Hong Kong if we are to build effective platforms for innovation.

Apart from "platform," another important element for "innovation development" is "process." Grouping and providing opportunities for the experts and specialists to share in "platform" is the first step. Yet, how to achieve the ultimate objective of innovation in higher education to have social impact is another important issue to take into consideration. Steven (2009) suggested that "process" in innovation including five different steps, which can be understood as "innovation cycle." First, the cycle begins with clarifying a problem that needs to be solved. Second, based on different experiences and situation, ideas are generated to solve that problem. Third, the idea is refined and tested. Forth, evidences or investment is captured and shared to pursue the development, and finally, there is an open feedback loop to enable continuous improvement and innovation. Thus, it is noticeable that "innovation" in not only limited to "technological advancement" or "sciences;" rather, inputting new idea into the traditional framework becomes an important ingredient for innovation. Besides, a combination 
of "platform" and "process" is important for achieving the social impact. In the followings sections, we are going to demonstrate how the three universities work out a "process" to achieve the innovation in higher education at their own pace.

\section{Review: Massachusetts Institute of Technology (MIT)}

According to QS, MIT has been ranked as the best in the world in 2012, above the likes of Harvard University, University of Cambridge and University of Oxford. ${ }^{4}$ MIT's mission is "to advance knowledge and educate students in science, technology and other areas of scholarship that will best serve the nation and the world in the 21 st century-whether the focus is cancer, energy, economics or literature. ${ }^{\prime 5}$ MIT is receiving attention as a center of innovation. In an article title "MIT and the art of innovation," it is reported that MIT has a strong partnership with local communities. "MIT calculates that its living alumni have founded 25,800 companies that currently provide $3.3 \mathrm{~m}$ jobs for people around the world. These firms have combined annual revenues of some \$2.2 trillion.”6 Innovation is now an important keyword of MIT. The institute is now famous for its OpenCourseWare, which provides free online education to web users. ${ }^{7}$

Here, we shall focus on Media Lab of MIT. The Media Lab was founded in 1985. It is an interdisciplinary research laboratory that "encourages the unconventional mixing and matching of seemingly disparate research areas." The current director is Mr. Joi Ito. Ito's background is not completely academic: he was the first CEO of a commercial internet service provider in Japan. Ito suggests "The Internet isn't really a technology, it's a belief system-a philosophy." ${ }^{8} \mathrm{He}$ continues,

The belief system of the Internet is that everyone should have the freedom to connect, the freedom to innovate and the freedom to hack without asking permission. No one can know the whole of it; it cannot be centrally controlled and the innovation happens in small groups on the "edges" of the network.

This belief system has created a massive network of distributed innovators. Internet innovators develop standards with each other and share the products of their work in the form of free and open source software. Lately they are even sharing electronics and physical designs. ${ }^{9}$

As the current director of Media Lab, Ito mentions some of his visions:

3D printers, laser cutters, online distribution, supply chain services and

${ }^{4}$ QS Ranking Calls MIT the world's Top Universities, Retrieved 15 December 2013 from http://web.mit.edu/newsoffice/2012/qs-rankings-names-mit-number-one-0911.html.

${ }^{5}$ Media Lab in MIT, Retrieved 15 December 2013 from http://web.mit.edu/aboutmit/.

${ }^{6} \mathrm{MIT}$ and the art of Innovation, Retrieved 11 September 2017

https://www.economist.com/blogs/babbage/2011/01/mit_and_art_innovation.

${ }^{7}$ MIT OpenCourseWare, Retrieved 15 December 2013 from http://ocw.mit.edu/.

${ }^{8}$ The Internet, Innovation and Learning, Retrieved 15 December 2013 from

http://joi.ito.com/weblog/2011/12/05/the-internet-in.html.

${ }^{9}$ The Internet, Innovation and Learning, Retrieved 15 December 2013 from

http://joi.ito.com/weblog/2011/12/05/the-internet-in.html. 
even sophisticated manufacturers have become cheaper, standardized and connected via the Internet. We are seeing the emergence of a community of hardware hackers and open hardware designs very reminiscent of the communities of developers who write the open standards and free and open source software of the Internet and I anticipate an explosion of grass-roots innovation around hardware as we saw in software. The Media Lab is very involved in all of the elements of this movement.

At the Media Lab, we have a multi-disciplinary group of faculty, students and member companies working together to invent the future by applying the philosophy of "rough consensus running code" to a wide variety of fields in addition to the future of hardware design.

At the Media Lab we focus on learning through creation instead of instruction. We are empowering individuals to experiment, create, and iterate. We produce demos and prototypes and share and collaborate with the rest of the world through the Internet and a distributed network of connections and relationships. We are not about centralized instruction but rather a node in a broad network of distributed creativity. ${ }^{10}$

Ito clearly shows that innovation is not equal to technological advancement. The Media Lab focuses on social impacts and changing the world, but it would not be achieved by technological advancement alone. Postgraduate students include programmers as well as artists. Research is not born in a professor's office, but in the open space of the Media Lab. Here, the most important issue is to ensure academic freedom and independence, and to promote interdisciplinary research. Innovation is impossible without crossing the borders between departments and faculties.

\section{Japan: Tohoku University (TU)}

Since its establishment in 1907, TU has been committed to two principles. "Tohoku University has been committed to the 'Research First' principle and 'Open Door' policy since its foundation, and is internationally recognized for its outstanding standards in education and research. The university contributes to world peace and equity by devoting itself to research useful in solving societal problems, and educating human resources in leadership skills." ${ }^{11}$ Like MIT, researchers in TU promote innovation. One month before the Great East Japan Earthquake in 2011, there was an international conference held in Tohoku University, Sendai. The aim of the symposium is to explore new science frontiers through weaving science web beyond particle-matter hierarchy. Here, the metaphor is to "weave a science web," which can tolerate the incommensurable by extensive interconnections among hierarchies. According to Kunio Inoue, who

\footnotetext{
${ }^{10}$ The Internet, Innovation and Learning, Retrieved 15 December 2013 from http://joi.ito.com/weblog/2011/12/05/the-internet-in.html.

${ }^{11}$ Mission Statement, Towards 2016, Retrieved 11 September 2017 from http://www.tohoku.ac.jp/en/about/mission.html.
} 
is the leader of the science web project,

This Science Web provides an environment to pursue deep studies and to explore new science frontiers and thus new challenging fields... it cooperates with the philosophy course and it challenges a new activity that removes the fence between Science and Liberal arts, too. It is convinced that a lot of unexplored science frontiers can be developed by promoting the cooperation among diverse fields, and many appear one after another top-class personnel having rich internationalism and a broad outlook. ${ }^{12}$

Science web is an ambitious project with a hope that new unexplored science frontiers will be developed by promoting the cooperation among diverse fields. The grand narrative here is clear: a web can be used to connect basic science and social interest, and eventually raises the intellectual level of humankind. However, in postmodern condition the matter becomes more and more complicated. This science web project is funded by a Japanese government program called GCOE (Global Centers of Excellence), which supports education and research centers "that can perform at the apex of global excellence to elevate the international competitiveness of the Japanese universities."13 The objective of the Japanese government is clear, but there is no guarantee that the support will last forever. As mentioned by Weber and Duderstadt,

Research universities face a particular challenge in acquiring the resources necessary for quality teaching and scholarship. Public budgets are increasingly strained by priorities such as the health-care requirements of an aging population, the burden of increasingly unsustainable social services, the need to replace ageing transportation and urban infrastructure, and the new security demands of an increasing dangerous world. Many citizens are becoming increasingly individualistic, stressing the priorities of private needs of a market-driven economy rather than addressing the public needs of a general population. As a consequence, the resources available to most universities simply cannot keep pace with the rising costs of excellence in higher education or the rising expectations of the societies they serve. (Weber and Duderstadt 2004: pp. 48, 241) [12]

At this moment, Japan is facing a huge economic crisis after 3.11. It is expected that the national budget on education might face a significant drop. Obviously, there is another funding source from the industrial sector, but it is equally problematic. Hashimoto Takehiko explains, "How to place emphasis among various topics during research (and education) at universities is clearly influenced by the prosecution of commissioned research and the like. But we should absolutely avoid the possibility that the selection of research planning be determined by the factor in conflict with the prerequisites of academic pursuits."

\footnotetext{
${ }^{12}$ To Establish a New Uniting Science from the Global COE, Retrieved 15 December 2013 from http://www.scienceweb.tohoku.ac.jp/publice/?page_id=10.

${ }^{13}$ Global COE Program, Retrieved 15 December http://www.jsps.go.jp/english/e-globalcoe/.
} 
(Hashimoto, 2009: p. 188) [13].

Perhaps the top priority of Tohoku University is not to remove the fence between science and liberal arts, but to bridge the gap between university and industry. In fact, Tohoku University became the university that patents the most in Japan in 2006. (Weber and Duderstadt, 2008: p. 103) However, how about the "knowledge transfer" from a teacher to a student? Without doubt, general education is becoming more and more important in research-oriented universities. According to James Duderstadt [14], there are different approaches in pedagogy. He suggests,

Some prefer the great books approach. As Bloom puts it, "Philosophy and liberal studies, in general, require the most careful attention to great books. This is because these are expressions of teachers such as we are not likely to encounter in person, because in them we find the arguments for what we take for granted without reflection, and because they are the sources of forgotten alternatives." Others argue for a more inquiry-based approach, stressing an acquaintance with the principal ways by which the human mind apprehends the world-that is, methods of understanding and inquiring about literature, art, moral philosophy, history, economy, and society, as well as natural sciences. Still others prefer a cafeteria approach, achieving breadth by requiring students to take a certain number of courses in each of several diverse categories such as the social sciences, natural sciences, humanities, and arts, assuming that different disciplines have separate and valuable ways of apprehending the world and that requiring students to sample a wide variety will suffice to broaden their minds.

In TU, there is a "Science Café" and a "Liberal Arts Salon," which are open lectures for those who are interested in science or liberal arts. ${ }^{14}$ Recently, TU promotes innovation by organizing "Innovation Fair"15 as well as launching "Innovation Leaders Platform." ${ }^{16}$ Although the campus of TU suffers from destruction due to earthquake two years ago, in post-311 era TU continues to promote knowledge transfer, with strong emphasis in innovative research and social impact to local communities. In this case, knowledge transfer is no longer a one-way path from university to the industry, but a two-way path providing more opportunities for innovative research.

\section{Hong Kong}

\subsection{Knowledge Transfer in Hong Kong}

Teaching in Hong Kong shows a lack of innovation; knowledge transfer is still technological oriented. This section will report the challenges and lessons learned during the course development of the Higher Diploma Programme in

\footnotetext{
${ }^{14}$ Science Cafe, Retrieved 15 December 2013 from http://cafe.tohoku.ac.jp/.

${ }^{15}$ Tohoku University Innovation Fair 2013, Retrieved 11 September 2017 from

http://www.rpip.tohoku.ac.jp/english/files/sangaku_e2013.pdf.

${ }^{16}$ ILP Innovative Leadership Platform, Retrieved 15 December 2013 from http://www.ilp.tohoku.ac.jp.
} 
Japanese Studies at The Open University of Hong Kong (OUHK).

The notion of knowledge transfer has been roughly introduced in Hong Kong since the early 1990s. The government has launched a number of policy initiatives that support innovation. In recent years, University Grant Committee (UGC) is increasingly promoting knowledge transfer in higher education. UGC defines knowledge transfer as follows: "The systems and processes by which knowledge, including technology, know-how, expertise and skills are transferred between higher education institutions and society, leading to innovative, profitable or economic or social improvements." ${ }^{17}$

The emphasis on innovation and social impact can be found in various documents issued by the UGC. For examples, the committee stresses in its mission statement that it will "support the continuous development of the higher education sector to achieve greater impact and recognition, and as a source of innovation and ideas for the community," ${ }^{18}$ or that "[a]cademic departments were encouraged to develop effective and innovative teaching and learning skills and pedagogies with more usage of web-based/e-learning and online multimedia materials" when explaining the " $3+3+3$ new academic structure" in its 2012-2013 annual reports. ${ }^{19} \mathrm{Up}$ to 2016 , it continues to encourage institutions 'to further strengthen and broaden their endeavours in transferring knowledge, technology and other forms of research outputs into real socio-economic benefits and impacts for the community and society' through the allocation of block grant, funding and incentives. ${ }^{20}$ The UGC has sought to address the issue of knowledge transfer in higher education.

Many universities in Hong Kong have included knowledge transfer in their strategic schemes and even set up special office in fostering this area after entering the 21 st century. The hardware seems to be ready. However, the concept remains theoretical. The outcome is yet to be seen. In 1997, Suzanne Berger and Richard Lester (1997: p. 66) [15], observed that "the universities hold themselves aloof from the industrial sector and do not tailor their teaching and research activities closely enough to needs." Almost a decade has passed since their publication of Made by Hong Kong, knowledge transfer, unfortunately, is still regarded as the third pillar (after research and teaching) by most universities.

Even though universities recognize the importance of innovation, they are struggling with the fundamental question: What to do? As Paul LeBlanc, President of Southern New Hampshire University, rightly explains the situation, "we seem to be sitting at the heart of a perfect storm where a lot of things are happening faster than our ability to predict and strategize. We can respond to this

${ }^{17}$ UGC Knowledge Transfer, Retrieved 11 September 2017 from http://www.ugc.edu.hk/eng/ugc/activity/knowledge.html.

${ }^{18}$ UGC Mission Statement, Retrieved 11 September 2017 from http://www.ugc.edu.hk/eng/ugc/about/overview/mission.html . ${ }^{19}$ UGC Annual Report 2012-13, Retrieved 11 September 2017 from http://www.ugc.edu.hk/eng/ugc/about/publications/report/AnnualRpt_2012-13.html. ${ }^{20}$ UGC Annual Report 2015-16, Retrieved from 11 September 2017 from http://www.ugc.edu.hk/eng/ugc/about/publications/report/AnnualRpt_2015-16.html. 
stormy weather... by simply waiting to see what arrives and then take action, often inadequately. Or we can recognize that we actually have the tools, the technology, and the know-how to reinvent U.S. higher education in ways that will address its current failings."21 Back to Hong Kong, a strong "platform" (beyond hardware in technology) with true dedication to innovation is needed.

\subsection{Bringing Innovation to the Japanese Studies Programme in Hong Kong}

Knowledge transfer is relatively easier to achieve in the science streams. Patenting and licensing are two pathways for the transfer of knowledge from universities to industry. Among all science disciplines, university research in biomedical field has more direct influences on industrial innovation and trigger R\&D projects (quoted from Mowery, 2014: p. 6). ${ }^{22}$ "Student and researchers' mobility from academe to industry is a critical mechanism to transfer knowledge from the university to industry, particularly when the knowledge to be transferred is hard to codify and is embodied in human capital as in the case for science-based knowledge. ${ }^{23}$ Hong Kong has relatively low R\&D investment when compared to the west, which explains the weak foundation of such transfer. That being said, art and social science streams encounter much greater difficulties as one can imagine.

According to a report delivered by the Knowledge Transfer Office of the Hong Kong Baptist University, knowledge transfer in arts and humanities "helps the public to enhance its understanding of individual and communal identities, cultures, ideas and beliefs, creativity, representation, and human communication." ${ }^{24}$

Aiming at true innovation in higher education, the Higher Diploma Programme in Japanese Studies at The Open University of Hong Kong has attempted to introduce work-integrated learning (WIL), along with other components, into the curriculum. WIL, broadly speaking, refers to educational programmes that incorporate workplace-based module. It is not only about company visit, placement or internship, but it emphasizes on producing benefits not only for students, but also employers. It gives students job readiness skills and knowledge for their future career.

Japanese Studies students from the Open University of Hong Kong have made a good start and it bombards the traditional framework of Japanese Studies which only focuses on language skills and cultural training. In 2015, students of the Higher Diploma in Japanese Studies of OUHK LiPACE were invited to sub-

\footnotetext{
${ }^{21}$ Building a Culture of Innovation in Higher Education: Design and Practice for Leaders, Retrieved 9 February 2017 from https://library.educause.edu/ /media/files/library/2015/4/ngt1502-pdf.pdf.

${ }^{22}$ David Mowery, Retrieved 9 Feb, 2017 from http://www.savantas.org/wp-content/uploads/2014/06/1_mowery.pdf.

${ }^{23}$ WWW for Europe, Retrieved 9 February 2017 from

http://www.foreurope.eu/fileadmin/documents/pdf/Workingpapers/WWWforEurope_WPS_no071_M S65.pdf.

${ }^{24}$ Hong Kong Baptist University Knowledge Transfer Annual Report, Retrieved 9 February 2017 from http://www.ugc.edu.hk/eng/doc/ugc/activity/kt/HKBU10.pdf.
} 
mit proposals on developing new ice-cream flavours for Milk Top, a Japanese ice-cream manufacturer. In order to brainstorm the best ideas, some students even conducted experiments at home and made their own home-made ice-cream. Then, all students were given a valuable opportunity to give presentations to real business clients, not professors in a simulated classroom.

Three submissions were selected and made available for sale for a period that lasted for ten months. The winning students were also offered the opportunity to work on-site as one-day branch managers, which is a unique culture in Japan. This activity recorded an interesting dialogue and dynamic synergy between the students and the employer: the former was able to transfer their knowledge and ideas into real products; the later also benefited from the youngsters' highly creative ideas. One of the students even became a personal assistant of Milk Top's CEO. This competition, incorporated with WIL components, gives students job readiness skills, knowledge and confidence.

Last but not least, a group of students from the same programme have established the Japanese Studies Society (Nikyusha), aiming to promote the appreciation of Japanese culture such as judo, tea ceremony and traditional dance. This shows a strengthening relationship among students and the community. Not only does it enhance student engagement, but also build social capital in the community.

"Individual innovativeness has traditionally been viewed as a trait, rather than a learnable competency." ${ }^{25}$ However, recent evidence shows that it can also be a learned behaviour (Dyer, Gregersen, \& Christensen, 2009 [16]). ${ }^{26}$ Seen in this light, appropriate learning programmes, along with effectual reasoning and substantial rethinking (Sarasvathy, 2001 [17]) can help nurture a student's innovativeness, as shown in the Milk Top example above. The Open University of Hong Kong, along with other universities and institutions, may still lack a good "platform", its baby step ("process") towards innovation in higher education has not gone unnoticed.

While the humanities are in crisis worldwide, this kind of non-technological innovation may bring more light to the discipline. This is especially true in Japanese Studies when "the state of the Japanese economy is less inspiring for foreign partners, who are moving some of their attention to other Asian countries, and the effects of globalization have made Japan itself also more accessible for outsiders without special knowledge." ${ }^{27}$ Raud (2016) [18], also pointed out in his keynote speech that the future will see more communication and collaboration among different disciplines in higher education. He encourages students to read for a minor which is fairly different from their major.

\subsection{Collaborative Innovation}

In the traditional education system, individual departments conduct their ${ }^{25}$ K. Celuch, B. Bourdeau and J. Smothers, 27.

${ }^{26}$ Quoted from Celuch et al., 27.

${ }^{27}$ Rein Raud, The 11th International Symposium on Japanese Language Education and Japanese Studies. 
teaching and research in their own ivory towers. Recently, cross-disciplinary collaboration received increasing attention. It is beneficial to bring this practice to higher education and allows more dialogues across different faculties and departments. In the UK, The Royal Society of Arts' Opening Minds curriculum, developed in 2000, "promotes innovative and integrated ways of thinking about education and the curriculum." It dedicates special lessons that give teachers and students the chance to explore cross-curricular topics in depth. "Schools which have embraced this approach have reported higher levels of staff satisfaction, along with greater levels of maturity and independence among students." ${ }^{28}$

In the "OUHK LiPACE Japanese Studies \& Milktop" example, the winning team took the initiative and invited peers from the Commercial Comic Art discipline to help design the product poster. The passion-driven project inspired students to start a cross-disciplinary collaboration. This is brilliant good example showcasing how innovation in education inspires students to think, create and leave an imprint in the commercial industry by producing a quality product. This small project is just a beginning for true revolution and evolution of innovative education.

\section{Concluding Remarks}

Innovation constitutes one of the big visions of 21 st century education in the context of globalization across different parts of the world. With the influx of information in a digital age, the role of teacher has drastically changed. Information is incredibly accessible through the Internet and students no longer rely on their teachers for the pure sake of getting information. Mass education should be replaced by personalized teachings and guidance that are relevant to the real world and adaptive to the interests of learners. "Niche-oriented institutions that provide specialized, career-enabling and life-enabling education" will succeed in nurturing students with skills that are valuable to the market. To achieve this, disruptive technological platforms which allow "diversity in terms of delivery models and blending oh high touch with personalized self-service" will be useful. Platform and process-digital technologies must go hand in hand with innovative teaching with excellent networks in order to get a true impact. Technology is not a panacea. One should remember that "there are no technology shortcuts to good education", as Kentaro Toyama puts it.

This paper has provided substantial definition of concept of innovation, and suggests some cases of successful innovation and social impact. From the reasoning above, we conclude that innovation and social impact are important in nowadays universities, which are no longer mere centers of research but also providers of teaching and knowledge transfer. We should not reduce the notion of knowledge transfer as a technological knowledge applied to business sector; rather, it is related to non-conventional interdisciplinary research that yields

\footnotetext{
${ }^{28}$ Martha Hampson, Alec Patton and Leonie Shanks, Retrieved 11 September 2017 from http://www.innovationunit.org/wp-content/uploads/2017/04/10-Ideas-for-21st-Century-Education. pdf.
} 
innovative ideas. As seen in cases of MIT and TU, innovation has its platform and process. To enhance knowledge transfer in Hong Kong, it is vital for funding authority to have a broader understanding of the idea of innovation. Fights for resources departmental, faculty or university levels may result in malicious competition, which will discourage innovative interdisciplinary research and non-research activities such as teaching and social impact. In Hong Kong as well as in some other regions, knowledge transfer is still regarded as the "third mission" (apart from teaching and research) of universities. The study on MIT and TU may provide a contemporary way of understanding the role of universities.

Based on the examination of the MIT, Tohoku University and The Open University of Hong Kong's experiences in this research, it provided a very good starting showcasing on how innovation in education inspires students to think, create and leave an imprint in the commercial industry by producing a quality commodity and this paper is believed that it is just a beginning for true revolution and evolution of innovative education.

\section{Acknowledgements}

The work described in this paper was fully supported by The Open University of Hong Kong Research Grant (No. 2015/1.8).

\section{References}

[1] Clements, J., British Film Institute (2013) Anime: A History. Palgrave Macmillan, London. https://doi.org/10.1007/978-1-84457-884-9

[2] Levi, A. (2013) The Sweet Smell of Japan: Anime, Manga and Japan in North America. Journal of Asian Pacific Communication, 23, 3-18.

[3] McCarthy, H., Tezuka, O. and Nihon Hoso- Kyokai (2009) The art of Osamu Tezuka: God of manga. Abrams ComicArts, New York.

[4] McWilliam, E. (2009) Teaching for Creativity: From Sage to Guide to Meddler. Asia Pacific Journal of Education, 29, 281-293.

[5] Gene, B. (2012) Globalization and Innovation: The Transformation of Higher Education in the 21st Century. The International Presidential Forum on Global Research Universities.

https://www.researchgate.net/file.PostFileLoader.html?id=54d9fdbfd3df3e27238b46 7f\&assetKey=AS\%3A273725360934912\%401442272619490

[6] Lyotard, J.-F. (1984) Postmodern Condition. Manchester University Press, Manchester.

[7] White, S.C. and Glickman, T.S. (2007) Innovation in Higher Education: Implications for the Future. New Directions for Higher Education, 2007, 97-105. https://doi.org/10.1002/he.248

[8] Goldsmith, M. Hesselbein, F. and Somerville, I. (2010) Leading For Innovation and Organizing Result. Jossey-Bass, San Francisco, 39-55.

[9] Giddens, A. (2001) Sociology : Introductory Readings (Rev. ed.). Polity, Cambridge.

[10] Clayton, C. (2012) Disruptive Innovations Create Jobs, Efficiency Innovations Destroy Them.

http://techcrunch.com/2012/10/09/clayton-christensen-disruptive-innovations-crea te-jobs-efficiency-innovations-destroy-them/ 
[11] Kim, S (2009) Innovation in Public Education: Education and Opportunities. https://www.google.com.hk/url?sa=t\&rct=j\&q=\&esrc=s\&source=web\&cd=1\&cad=r ja\&uact=8\&ved=0ahUKEwj63-nGr5zWAhUHFpQKHZkBCWMQFggpMAA\&url= http\%3A\%2F\%2Fpahara.org\%2Fwp-content\%2Fuploads\%2F2012\%2F12\%2Finnova tion-in-education.pdf\&usg=AFQjCNHPXrLLbx0NmM9sryuC8y4_QdMKQA

[12] Celuch, K., Bourdeau, B. and Smothers, J. (2014) Thinking Innovatively about Teaching Innovation and Ideation: Getting Students to Think Differently. The Journal of Research in Innovative Teaching, 7, 27-36.

http://www.nu.edu/assets/resources/pageResources/journal-of-research-in-innovati ve-teaching-volume-7.pdf

[13] Hashimoto, T. (2009) Historical Essays on Japanese Technology. University of Tokyo Center for Philosophy, Tokyo.

[14] Weber, L.E. and Duderstadt, J.J. (2008) The Globalization of Higher Education. Economica, London.

[15] Berger, S. and Lester, Richard K. (1997) Made by Hong Kong. Oxford University Press, Hong Kong.

[16] Dyer, M. (2014) University-Industry Collaboration and Technology Transfer in Hong Kong and Knowledge-Based Economic Growth. http://www.savantas.org/wp-content/uploads/2014/06/1_mowery.pdf

[17] Sarasvathy, S.D. (2001) Causation and Effectuation: Toward a Theoretical Shift from Economic Inevitability to Entrepreneurial Contingency. Academy of Management. The Academy of Management Review, 26, 243-263.

https://search.proquest.com.ezproxy.lib.ouhk.edu.hk/docview/210984203?accountid $=16720$

[18] Raud, R. (19 November 2016) Keynote Speech. The 11 th International Symposium on Japanese Language Education and Japanese Studies.

\section{Submit or recommend next manuscript to SCIRP and we will provide best service for you:}

Accepting pre-submission inquiries through Email, Facebook, LinkedIn, Twitter, etc. A wide selection of journals (inclusive of 9 subjects, more than 200 journals)

Providing 24-hour high-quality service

User-friendly online submission system

Fair and swift peer-review system

Efficient typesetting and proofreading procedure

Display of the result of downloads and visits, as well as the number of cited articles

Maximum dissemination of your research work

Submit your manuscript at: http://papersubmission.scirp.org/

Or contact jss@scirp.org 